\title{
Dorota Rzeszewska
}

(Uniwersytet im. Adama Mickiewicza w Poznaniu, Poznań - Polska)

\section{SYJONIDY I ICH MIEJSCE WE WSPÓLCZESNEJ ROSYJSKIEJ KULTURZE}

Poznanie historii syjonid i zrozumienie istoty tego gatunku lirycznego nie jest możliwe bez przypomnienia sylwetki ich pierwszego twórcy, Jehudy Halewiego. Ten Żyd urodzony w XI wieku w muzułmańskiej wówczas Hiszpanii to postać nieprzeciętna, Leonardo swoich czasów. Wszechstronnie wykształcony, praktykujący lekarz, kupiec i finansista, a także teolog judaizmu i filozof zaczytujący się po arabsku w Platonie i Arystotelesie, piszący własne teologiczno-filozoficzne rozprawy był jednocześnie niezwykle utalentowanym i płodnym poetą (do dziś przetrwało ok. 800 jego utworów). Mistrzowski warsztat pisarski zawdzięczał doskonałej znajomości współczesnej sobie arabskiej nauki o literaturze i, rzecz jasna, hebrajskiej biblii ${ }^{1}$. Z kolei doświadczenia życiowego dostarczyły mu historyczne wydarzenia, jakich był mimowolnym świadkiem² ${ }^{2}$ Zetknięcie się z biedą swoich współbraci rozsianych po Półwyspie Iberyjskim, której sam jako człowiek zamożny nie doświadczał, pogłębiającą w nich pamięć wygnania i tęsknoty za Ziemią Świętą, przywiodło Halewiemu na myśl porównanie do Psalmu 137(136).

Dziś ta pieśn Dawida funkcjonuje w świadomości masowej m.in. dzięki wykonaniu zespołu Bony M (By the rivers of Babylon), ale Halewi, rzecz jasna, nie mógł znać tego wykonania. Zbiorowym podmiotem lirycznym psalmu są Żydzi wysiedleni z Judei do Babilonii po zburzeniu Pierwszej Świątyni. Płacząc na obcej ziemi, wspominają oni swą utraconą ojczyznę („Nad rzekami Babilonu - tam myśmy siedzieli i płakali, kiedyśmy wspominali Syjon"3). Judejscy muzykanci i śpiewacy cieszyli

${ }^{1}$ М. Гельман, Звезда своей эпохи, „Мигдаль Times” 2008, № 92, http://www.migdal.ru/ times/92/16466/ (20.10.2011).

2 Jehuda Halewi urodził się w 1075 r. w Toledo, u schyłku złotego wieku islamu, kiedy jeszcze muzułmanie, żydzi i chrześcijanie żyli w Hiszpanii w zgodzie. Pod koniec XI w. Hiszpanię zdobyli fanatyczni Berberysi. Początkowo poeta uciekł do spokojniejszej chrześcijańskiej Katalonii, następnie podróżował po półwyspie. Zob.: М. Гельман, Звезда своей эпохи ..., op. cit.

${ }^{3}$ Syjon był początkowo nazwą jednego z dwóch wzgórz jerozolimskich, na którym stała twierdza zdobyta przez Dawida. Salomon w obręb miasta włączył drugie wzgórze, na którym wybudował Świątynię i pałac. Od tego czasu z nazwą Syjon zaczęto utożsamiać całą Jerozolimę, następnie Judeę, potem Palestynę. Dla Żydów rozsianych po świecie po zburzeniu Świątyni Syjon stał się symbolem Ziemi Obiecanej. Tłumaczenie Psalmu 137 z Biblii Tysiąclecia. 
się sławą wybitnych, Babilończycy proszą ich zatem o zaśpiewanie pieśni. Żydzi odmawiają ciemiężycielom („Na topolach tamtej krainy zawiesiliśmy nasze harfy. Bo tam żądali od nas pieśni ci, którzy nas uprowadzili, pieśni radości ci, którzy nas uciskali: Zaśpiewajcie nam jakąś z pieśni syjońskich!"), ale, co może ważniejsze, nie chcą i nie mogą na obcej ziemi śpiewać pieśni przeznaczonych do wykonywania w Swiątyni („Jakże możemy śpiewać pieśń Pańską w obcej krainie?”) ${ }^{4}$. Do kraju wygnania zabrali pamięć o Jerozolimie (,Jeruzalem, jeśli zapomnę o tobie, niech uschnie moja prawica! Niech język mi przyschnie do podniebienia, jeśli nie będę pamiętał o tobie, jeśli nie postawię Jeruzalem ponad największą moją radość").

Jehuda nie był w Jerozolimie, podobnie jak zapewne jego rodzina, sąsiedzi, wszyscy Żydzi, których spotykał. A jednak sytuacja wygnania i tęsknota za duchową ojczyzną wydały mu się analogiczne. Upust swoim odczuciom dał w cyklu wierszy Szirei Cion (hebr. Pieśni Syjonu). Najsłynniejszy z nich ${ }^{5} \mathrm{w}$ rosyjskim tłumaczeniu zaczyna się słowami:

Сион, неужто ты не спросишь о судьбах узников твоих...6.

Halewi odwrócił w nim jednak sytuację. To nie Babilończycy prosili w nim Żydów o pieśni, a Żydzi prosili Syjon o zainteresowanie ich losem w obcej ziemi. Halewi zmienił też hebrajskie słowo oznaczające "ci, którzy nas uprowadzili (uwięzili)” na „więźniowie”, co nadało mu znaczenia niewoli duchowej, miłosnej. Metaforę „więzień miłości” zaczerpnął poeta $\mathrm{z}$ hebrajskiej liryki miłosnej, w której stosowana była powszechnie, i uczynił Żydów „więźniami Syjonu” spętanymi okowami miłości ${ }^{7}$. Przenośnia Halewiego jest tu o tyle uzasadniona, że słowa Syjon, miasto i Jerozolima po hebrajsku są rodzaju żeńskiego ${ }^{8}$.

Elegia Jehudy Halewiego dała początek nowemu gatunkowi liryki nazwanemu od tytułu cyklu Pieśni Syjonu - syjonidą. Stała się także jego wzorcem gatunkowym. Wymienić można następujące podstawowe jej cechy: Syjonida jest pisana zawsze daleko od Syjonu, wspomina Żydów jako zbiorowość, opisuje Ziemię Świętą jako należącą do Boga przy po-

${ }^{4}$ В. Вакульчик, Жанр сиониды в лирике Йегуды га-Леви („Узники Сиона”), [w:] Сборник тезисов 63-й научно-практической конференции аспирантов, магистрантов и студентов, под ред. А.В. Шарапо, Минск 2006, s. 98.

${ }^{5}$ Do dziś jest odczytywany co roku w synagogach w święto Tisza beAw (upamiętniające zburzenie Świątyni).

${ }^{6}$ И. Галеви, Стремление к Сиону, http://callofzion.ru/pages.php?id=529 (01.07.2011).

73. Копельман, Сионида - паломничество души (к динамике жанра), „Вестник еврейского университета" 2001, № 6(24), s. 131.

8 W Biblii często spotykane jest określenie miasta-matki i miasta-oblubienicy. Żona pojawia się dopiero w Nowym Testamencie. Zob.: И.Г. Франк-Каменецкий, Колесница Иеговы. Труды по библейской мифологии, Москва 2004, s. 224-225. 
mocy metafor zaczerpniętych z Biblii, w szczególności z Pieśni nad Pieśniami, $\mathrm{z}$ innych środków stylistycznych pojawiają się $\mathrm{w}$ niej często hiperbolizacje i przeciwstawienia, podmiot liryczny marzy o skrzydłach i lataniu, by móc polecieć do Ziemi Świętej. Ale najważniejsza jest dla syjonidy opozycja: poeta (mężczyzna) - ojczyzna (kobieta). Kończy się klasyczna syjonida zawsze przejściem od marzeń do realnej sytuacji podmiotu lirycznego'.

Od czasów Jehudy Halewiego minęły wieki. Dziewiętnastowieczni ojcowie literatury rosyjsko-żydowskiej zdecydowali się tworzyć pierwsze żydowskie utwory po rosyjsku, podejmując świadomą decyzję wejścia poprzez język do kultury wschodniosłowiańskiej. Była to bodaj najmocniej w historii determinowana sytuacją polityczną synteza literatury żydowskiej z nieżydowską. Nie dziwi zatem fakt, że na przełomie wieków równolegle z rozwojem najsilniejszego w Europie rosyjskiego syjonizmu rozkwitły w literaturze rosyjsko-żydowskiej syjonidy. Palestyna była wtedy dla poetów nie tylko krajem, do którego chcieli emigrować, ale symbolem tej doskonałości, do której dąży dusza. Pieśni Syjonu pisał Lejb Jaffe, Saul Czernichowski, Korniej Czukowski, Siemion Frug i wielu innych. Pisał także Samuel Marszak - znany radziecki twórca literatury dziecięcej, któremu fakt wydania w młodości tomiku wierszy Сиониды przyszło ukrywać przez całe życie.

Kiedy duchowy syjonizm ustąpił miejsca syjonizmowi praktycznemu, czyli kiedy Żydzi, w tym Żydzi rosyjscy, zaczęli zasiedlać Palestynę, gatunek chwilowo się wyczerpał. Po pierwsze, nie było już potrzeby tęsknić za daleką Ziemią Świętą, bo prędzej czy później syjoniści wyjeżdżali do Palestyny, a po drugie charakterystyczna dla syjonidy stylistyka sentymentalna została wyparta przez inne estetyki ${ }^{10}$. W tym czasie wyrażenie „узники Сиона” nabrało innego, nieliterackiego znaczenia - nazywano tak uciskanych przez władze żydowskich osadników w czasie brytyjskiego mandatu nad Palestyną ${ }^{11}$.

Wyrażenie "узники Сиона" ma i trzecie znaczenie. Są to Żydzi, którzy w Związku Radzieckim z jednej strony byli prześladowani za pochodzenie, z drugiej nie mogli wyjechać z kraju, gdzie ich „nikt nie trzyma"12. W latach trzydziestych i pięćdziesiątych przeżywali okresy wzmożonych represji i aresztowań o jawnie antysemickim charakterze ${ }^{13}$.

9 3. Копельман, Сионида..., op. cit., s. 132-134. Cechy gatunkowe syjonidy podano w uproszczeniu w stosunku do klasyfikacji podanej przez Zoję Kopelman.

${ }^{10}$ Ibidem, s. 140.

${ }^{11}$ Краткая еврейская энциклопедия, под ред. И. Орена, М. Занда, Н. Прата, А. Авнера, Иерусалим 1976-2005, kol. 1168-1169.

12 Zob.: В. Лихт, Узники Сиона, http://webprogulki.com/sion_23_09_04.html (31.10.2011).

13 Zob.: A. Цинкер, Сталинский режим и узники Сиона, "Самиздат” 2001, http://zhurnal. lib.ru/a/aleksandr_c/uz1.shtml (20.10.2011). 
Ciężko jest znaleźć syjonidy z tego okresu, chociaż zdarzało się je przemycić w druku. Niektóre $\mathrm{z}$ wierszy Osipa Mandelsztama, szczególnie wczesnych, które współcześni badacze odczytują przez pryzmat religii i tradycji żydowskiej, wcześniej niejasne i niezrozumiałe, okazują się być poszukiwaniami żydowskiej tożsamości, a zdarzają się wśród nich i syjonidy ${ }^{14}$. W latach pięćdziesiątych po odwilży postalinowskiej Dawidowi Markiszowi, bratu słynniejszego dziś Szymona, udało się nawet wydrukować jedną syjonidę w oficjalnym czasopiśmie, jednak resztę - cały cykl Сиониды wydał w samizdacie ${ }^{15}$.

Okazuje się, że dziś nadal jest miejsce dla pieśni Syjonu. Rosyjski Internet żyje mniej lub bardziej wpisującymi się w ramy gatunku syjonidami - od klasycznych po nowoczesne, od religijnych po bluźniercze. Dla jednych młodych współczesnych poetów natchnieniem jest tęsknota za Ziemią Świętą spowodowana trudnościami w zrobieniu aliji czyli $\mathrm{w}$ otrzymaniu izraelskiego obywatelstwa i zamieszkaniu w Erec-Israel, dla innych (niekoniecznie Żydów) liryka Jehudy Halewiego stanowi tylko punkt wyjścia, inspirację dla własnych twórczych eksperymentów.

Niebezpieczeństwo pójścia tym tropem, wyjścia za daleko poza ścisłe ramy gatunku i zwiększenia pojemności pojęcia syjonidy dostrzegł Oleg Dart, formułując pewien analityczno-literacki żart, dotyczący wiersza Aleksandra Puszkina o Adamie Mickiewiczu:

Я знаю одну отличную сиониду. Там так: „Он между нами жил // Средь племени ему чужого... Он посещал беседы наши... Он говорил о временах грядущих, //Когда народы, распри позабыв, // В великую семью соединятся... Он // Ущел на запад... Но теперь // Наш мирный гость нам стал врагом..." и пр. (выделено мной - О.Д.). Возможная интерпретация. „Он” - еврейский народ в рассеянии, в душе мирный. Но и участвуя в чужой культуре (см. в стихотворении: „делились... мечтами”), „он” не оставлял надежду на восстановление храма („грядущие времена”). „Народы, позабывшие распри” - колена израильские, которые „соединятся”. Почему ушел на запад? Обычный путь переселенцев - через Австрию... Дальше над текстом и думать боюсь ${ }^{16}$.

Chociaż więc w stricte literaturoznawczym ujęciu nasuwają się wątpliwości co do przystawalności badanego materiału do wzorca gatunkowego, to jednak po dodaniu perspektywy kulturowej prześledzenie kierunku ewolucji syjonid wydaje się być mimo wszystko interesujące. Już samo odnotowanie istnienia w czasach współczesnych zjawiska pieś-

${ }_{14}$ С. Чарный, Осип Мандельштам: мускус иудейства, http://www.gesharim.org/reviews/ ?reviews_id=22 (20.10.2011).

15 И. Толстой, Маркищ, сын Маркища, http://www.svobodanews.ru/content/transcript/ 24200059.html (31.10.2011).

${ }^{16}$ О. Дарк, Ночь иудейская, http://old.russ.ru/krug/kniga/20021225_dark.html (31.10. 2011). 
ni nawiązujących do jedenastowiecznej tradycji, będącego wyrazem tęsknoty za wolnym, demokratycznym krajem, do którego nic nie stoi na przeszkodzie jechać, warte jest odnotowania.

I tak na przykład na izraelskim forum internetowym znaleźć można cykl wierszy Сиониды, którego autor wyznaje:

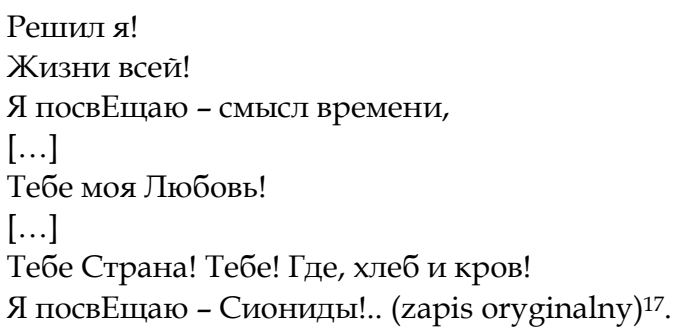

I dalej poeta zamieszcza trzy kolejne wiersze zatytułowane Сиониды, które są interesującymi wierszami o ojczyźnie, ale nie syjonidami. Zasługuje jednak na uwagę ostatni utwór z tego cyklu:

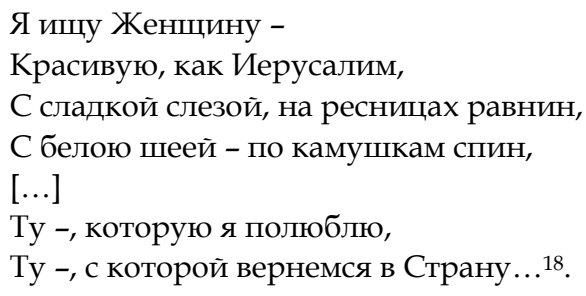

Można w nim odnaleźć pewne cechy syjonidy: porównanie Jerozolimy do kobiety, piękne metafory i tęsknota podmiotu lirycznego do Kraju, który jest daleko. Określenie „вернемся” - wrócimy może mieć tutaj znaczenie przenośne, powrotu do kraju ojców.

W podobnej sytuacji jest być może podmiot liryczny utworu Mariny Kniaziewy Признание $\mathrm{b}$ ююби. Adresatem wyznania miłosnego jest tu ir Dawid - miasto Dawida czyli Jerozolima. Autorka pisze:

$$
\begin{aligned}
& \text { я сгораю от этой разлуки, } \\
& \text { как трава - от разлуки с землей }{ }^{19} \text {. }
\end{aligned}
$$

Nie wiadomo jednak, co oznacza tutaj dla podmiotu lirycznego „разлука". Czy rozłąka owa jest chwilowa i fizyczna, czy wieczna, duchowa.

$\mathrm{Z}$ kolei w wierszu Zinaidy Priadko podmiot liryczny opisuje finał podróży do Izraela, moment zbliżania się do Jerozolimy. Nie można nie

\footnotetext{
17 Израильский форум, Сионида № 1-5766, http://forum.israelinfo.ru/viewtopic.php?t $=20714$ (01.07.2011).

18 Ibidem.

${ }^{19}$ М. Князева, Признание в любви, http://third.forum9.biz/t144-topic (01.07.2011).
} 
wspomnieć w tym miejscu Jehudy Halewiego, który - jak głosi legenda - zmarł z syjonidą na ustach zadźgany przez saracena u bram Jerozoli$\mathrm{my}^{20}$. Ja liryczne wiersza Priadko pozostaje wciąż poza obszarem opiewanego w wierszu Syjonu, choć dystans jest już niewielki:

\section{Вот эти холмы крутые \\ Во сне уже видела я ${ }^{21}$.}

Mamy zatem motyw snu, marzeń.

$$
\begin{aligned}
& \text { И вижу как радугу в небе } \\
& \text { Раскинул святой Отец: } \\
& \text { „Завет Мой - с тобой! Дочь родная } \\
& \text { Вернулась ко Мне, наконец!”22. }
\end{aligned}
$$

Jest więc i motyw Ziemi Świętej jako należącej do Boga. W końcu następuje wyznanie:

$$
\text { „Теперь я твоя!"23. }
$$

Należy jednak zwrócić uwagę, że zarówno czyniąca wyznania, jak i ich adresatka są kobietami, bowiem „ziemia”, do której się zwraca podmiot liryczny, jest rodzaju żeńskiego $\mathrm{w}$ obu interesujących nas językach. $\mathrm{W}$ dzisiejszych czasach nie ma $\mathrm{w}$ tym niczego nadzwyczajnego, ale nie jesteśmy pewni, czy gatunek jest tak obszerny, by i taki porządek pomieścić.

Problem czystości gatunkowej występuje także w wierszu Michaiła Polskiego:

$$
\begin{aligned}
& \text { Я не знал, что жена мне Святая Земля, } \\
& \text { И женился ещё на другой. } \\
& \text { Та земля родила мне детей. У меня } \\
& \text { Дети связаны с тою землёй. } \\
& \text { А Святая моя безутешна Жена: } \\
& \text { Бросил, предал, нарушил Завет... } \\
& \text { И с безмолвным укором глядит на меня } \\
& \text { И пред ней оправдания нет } 24 .
\end{aligned}
$$

Swój kłopot rozwiązuje pomiot liryczny „oddając” swą niedoszłą świętą żonę kolejno synowi i wnukom, a my pozostajemy z podejrzeniem, że utwór nie jest syjonidą, pisany jest bowiem z perspektywy Syjonu, a nie oddalenia.

${ }^{20}$ М. Гельман, Звезда своей эпохи ..., ор. cit.

21 3. Прядко, На корабле Фарсисском, „Зов Сиона” 2008, № 48, s. 15.

22 Ibidem.

${ }^{23}$ Ibidem.

${ }^{24}$ М. Польский, Жена, http://jerusalem-temple-today.com/perev/UZG/kamenev/polsky. now.html (01.07.2011). 
Można jednak znaleźć i takie perełki, jak utwór Иерymaлаuм Beniamina Gitlica, idealnie wpisujący się w gatunek.

\author{
Мне бы только пылинку Твоей земли \\ Мне бы только былинку, что там росла, \\ Просветленный взор мой увидит вдали \\ Твоих холмов купола! \\ Стать росинкой на камне Твоей стены, \\ Отразить Твое небо в начале дня, \\ Пропитаться дыханием Твоей страны, \\ Что влечет и манит меня. \\ Я лишь малый листочек в Твоём лесу, \\ Но веками в еврейской крови моей \\ Драгоценнейший клад наследства несу \\ От библейских до наших дней. \\ Верю я, будет радость в сердцах людей, \\ Будет мир меж народами всех земель. \\ И услышится Голос: „Я вернулся к тебе. \\ Шма, Исраэль $25 ! " 26$.
}

Wiersz pisany w konwencji erotyku od pierwszych wersów zdradza, że obiektem uczuć wyrażanych przez podmiot liryczny jest nie kobieta, a Jerozolima. Podmiot liryczny wiersza wyraża przynależność do narodu żydowskiego i czuje związek z jego wielowiekową historią. A będąc cząsteczką narodu razem z miastem, które go przywołuje i przyciąga, należy do Boga. Skłaniający do refleksji jest jednak jeden wers - niepasujący do wiersza miłosnego, ze sloganem rodem nie ze Starego Testamentu, a raczej $\mathrm{z}$ niedawno minionej epoki, wtrąconym, wydawałoby się, nieco bez związku, a zrozumiałym dopiero w kontekście współczesnej historii Izraela. Wyrażona w nim wiara, iż „będzie pokój pomiędzy narodami świata" jest owym znakiem czasów odciśniętym na syjonidzie.

${ }^{25}$ Шма Исраэль! (hebr. szma Israel, Adonaj Elochejnu, Adonaj echad, Słuchaj Izraelu, Pan [jest] naszym Bogiem, Pan [jest] jeden). Najważniejsza modlitwa judaizmu, Wyznanie wiary.

${ }^{26}$ В. Гитлиц, Иерушалаим, http:// tikvaisrael.com/poetry.html (01.07.2011). 